\title{
Executives Characters, Gender and Tax Avoidance: A Study on Manufacturing Companies in Indonesia
}

\author{
Nova Novita \\ STIE Indonesia Banking School \\ nova.novita@ibs.ac.id
}

\begin{abstract}
This paper investigates the effect of executives character and gender on corporate tax avoidance. Gender in this research is measured by dummy variable, executives character is measured by the company risk, while tax avoidance is measured by the cash effective tax rate. Data analyzed consisted of 20 manufacturing companies from 2009-2014, and this research used 120 observations. The results showed that the executive character negatively affect tax avoidance. While male executives in this study proved to be more courageous in taking tax avoidance risk, when compared with women executives. Although executives character at the companies are basically a risk taker, in the case of tax avoidance, they tend to be more cautious because of Taxes Law. This may be explained that reputation is damaged due to violation of tax rules is not outweighed by the benefits form tax avoidance.
\end{abstract}

\section{Key words: Tax Avoidance, Gender, executives character}

\section{INTRODUCTION}

Indonesia is a country that relies on tax revenue to finance the administration and development of state. The government tried to raise tax revenue in all sectors of the economy which exists to maximize the potential tax revenue. There is an interests difference between the government and the taxpayer [1]. Taxpayers paid taxes as small as possible because taxes reduced the economic ability of taxpayers. On the other hand the government needs money to manage the country that derived from taxes. The conflict of interests between taxpayers and government, making the issue of tax avoidance both legally and illegally became interesting debate.

Tax avoidance committed by a company, usually through decision taken by the executives [2]. An executive as decision makers in the company certainly has a different character with other company executives. Character or behavior of the corporate leaders can be risk-taking, risk-averse, or are riskneutral. Thus the character of the executives of the company in terms of risk-taking level will be reflected at the level of risk faced by the company.

Executives play an important role in determining the level of tax avoidance in the company [3]. Research also showed that the company leaders (Executive) individually have a significant role to the level of corporate tax avoidance [4]. The study found that a risk-taker executives tends to made an aggressive tax avoidance policy than the risk averse executives [5]. Other research found that executives character does not have influence on their decisions in tax avoidance [6] [7].
Different results also found that the executive character does not have influence on their decisions in determining the tax rate [8] [9].

The differences between male and female characters will influence the attitude and action taken. There is a common view that women are generally more risk-averse than men. Numerous studies have tried to prove that view. Some study tried to compared the women and men executive's character in terms of tax avoidance [10] [11]. The results showed that female CFOs less aggressiveness in tax avoidance than male CFOs. Likewise, some research found that gender has a positive effect on tax avoidance [12]. Nevertheless, a number of the literature found that there is no difference in terms of ethics or obedience taxes between men and women [13] [14]. others research failed to find any link between gender with tax avoidance [15] and gender was not associated with high and low levels of tax morality [16]. The purposes of this study is provide empirical evidence about the effect of gender on the character of the executive and corporate tax avoidance. This research is expected to add empirical evidence of the variables tested.

\section{LITERATURE REVIEW AND HYPOTHESES DEVELOPMENT}

\section{A. 2.1 Tax Avoidance and Executives Characters}

Tax avoidance is a topic that has attracted researchers for decades. Tax avoidance define broadly to all policy aimed to reducing the corporate tax relative to income before taxes [17]. Tax avoidance conducted by the company is done through policy taken by the company [18]. In terms of courage in their policy of tax avoidance, will be influenced by the character of the executive (of directors) of the company. The sustainability and development opportunities of the company associated with risk-taking financial decisions taken by managers [19]. Tax avoidance strategy is designed to create an asymmetry of information between the government and the company, so it is not detected by the government [2] [17]. Largely research related on top management has always been associated with the company's performance, only a few are tested on corporate tax avoidance [3].

Prospect theory explains the differences in individual attitudes toward risk, especially regarding the profit and loss [18]. People willing to earn a lower income to avoid losses are risk averse, and vice versa [19]. In other words, the theory states that the individual's sensitivity to the loss is two times greater than the sensitivity of the profit. 
Executive effects on firms' effective tax rates, examined by constructed a data set that tracks the movement of 908 executives across firms over time [3]. The results indicate that individual executives play a significant role in determining the level of tax avoidance that firms undertake. Results indicate that individual executives play a statistically and economically significant role in determining the level of tax avoidance that firms undertake. Whether managers that have a propensity for personal tax aggressiveness are associated with tax avoidance at the firm level had investigated [20]. The results indicate that aggressive managers are associated with firm-level tax avoidance.

Researcher investigates whether the executives character, audit committees, firms size, leverage and sales growth are associated with tax avoidance [5]. This research was conducted on manufacturing firms in Indonesia Stock Exchange (IDX) 2011-2013. The results of this study indicate that the executive's character and firms size has a positive effect on tax avoidance, while the negative effect of leverage on tax avoidance. Audit committee variables and sales growth has no effect on tax avoidance. The influence of executive's character and political connections against tax avoidance had examined [6]. The sample used in this study are 74 companies from nonfinancial companies listed on the Indonesia Stock Exchange during 2009-2013. The results showed that executive's character and political connections have a significant effect on tax avoidance. Other research assessed the influence of executive character in the company on tax avoidance [4]. The results of this study that executives who have the character of risk takers had significantly positive effect on tax avoidance.

Based on theoretical and research findings above, my first hypothesis in this study is:

H1: There is a positive association between character of executives and tax avoidance.

\section{B. Tax Avoidance and Gender}

The gender differences in risk-taking behaviors have been explored extensively in both the psychology and economics literature. Extant studies suggest that women in the general population are more risk averse than men [21] [22]. Some studies find that female executives are associated with less earnings management [23], more conservative accounting [24], and less risky financing and investment decisions [25]. Others argue that women who are more risk-tolerant self-select into the managerial professions; thus, their risk preferences are not different from those of their male counterparts [26] [27].

Tax avoidance is as the illegal nonpayment of a tax [12]. They examined and summarized the main arguments and incorporated them into a survey instrument that was distributed to 200 university students in China and 161 in the United States to determine the relative strengths of 18 historical arguments that have been used to justify tax avoidance in the past. A comparison of rankings and mean scores found that, overall, the Chinese were significantly more opposed to tax avoidance in 10 cases and significantly less opposed to tax avoidance in two cases. Chinese women were more opposed to tax avoidance than were Chinese men in all 18 cases; the opposition was significantly stronger in 10 cases. For the US sample, men were significantly more opposed to tax avoidance than women in one case; for the other 17 cases, the differences in mean scores were not significant.

A review of dozens of studies that have been conducted on ethics from a gender perspective, then proceeds to present the results of a study of 23 Asian and 11 European countries on the ethics of tax avoidance [14]. The study found that, although there is widespread opposition to tax avoidance, many of the more than 50,000 respondents believe that tax avoidance is ethical in some cases. In most of the countries included in the study, women were significantly more opposed to tax avoidance. However, in more than a dozen countries, there was no significant difference between male and female opinion. In two countries, men were significantly more opposed to tax avoidance than were women. The study also includes a bibliography of more than 80 tax avoidance studies that focused on ethical issues, along with links to most of those studies.

The effect of CFO gender on corporate tax aggressiveness had investigated [24]. They find that female CFOs are associated with less tax aggressiveness as compared to their male counterparts. Overall, their study establishes CFO gender as an important determinant of tax aggressiveness. The Determinants of personal income tax compliance had examined [13]. The findings show that there is a significant positive relationship between tax rate and personal income tax compliance; the perception of taxpayers' of the Government of the day has a significant impact on how they comply with personal income taxation; taxpayers' income has a significant impact on personal income tax compliance; the gender of the taxpayer has no significant positive relationship with his/her level of tax compliance; and the attitude of taxpayers to the tax system has a significant impact on personal income tax compliance.

The factors that have effect corporate taxpayer compliance, especially the corporate taxpayer in KPP Pratama Cengkareng, west Jakarta had analyzed [10]. The respondents of the study are tax professionals who have at least one year experience as tax professionals in the corporate. One hundred tax professionals of 5408 corporates participated in this study. Data analysis to the hypothesis is logistic analysis. The result of this research show that, the effect of : 1) attitude toward is positive and significant; (2) Gender of tax professionals is positive and significant; (3) Moral tax professionals is positive and significant. The effect are not significant : Age, Education, Income level, environs tax professionals.

Based on theoretical and research findings above, my second hypothesis in this study is:

H2: Male Executives are associated with higher levels of tax avoidance.

\section{ReSEARCH MethodOLOGY}

This research investigates executive's character, gender and their influence to tax avoidance. This research is categorized as a descriptive and causal research. The population used is manufacturing companies, listed in Indonesia Stock Exchange from 2009-2014. Tax avoidance as dependent variable measured by cash effective tax rate, defined as cash tax paid 
divided by pre-tax book income before special items [3]. Executive character measured by corporate risk. Corporate risk can be measured by the standard deviation of corporate earnings [29][3]. The risk-adjusted measure of EBITDA/Assets is calculated by dividing the average profitability measure EBITDA/Assets by the standard deviation of corporate earnings (RISK). EBITDA is earnings before interest, taxes, and depreciation. As CEO is one of the most important decision makers for corporate, then this formula will reflected their risk preference.

$$
R I S K=\sqrt{\sum_{T-1}^{T}\left(E-1 / T \sum_{T-1}^{T} E\right)^{2} /(T-1)}
$$

This research also used control variables such as leverage, sales growth, net operating loss and inventory intensity. Leverage, defined as the sum of long term debt divided by total assets. Sales GrowthMeasured by the annual percentage change in sales ((Salest/ Salest-1)-1). Net Operating Loss (NOL) as indicator if the firm has non missing value of tax loss carryforward, 1 if company has loss and o if not. Inventory Intensity (INVINT) is calculated by total inventory divided by total assets [30]. Research model used to test the hypothesis of this study are as follows:

CASHETR $_{i t}=\beta_{0} i t+\beta_{1}$ RISK $_{i t}+\beta_{2}$ LEVERAGE $_{i t}+\beta_{3}$ $S A L E S G R_{i t}+\beta_{4} N O L_{i t}+\beta_{5} I N V I N T+\varepsilon_{i t}$.

Where:

$$
\begin{array}{ll}
\text { CASHETR }_{\mathrm{it}} & =\text { Cash Effective Rate } \\
\text { RISK }_{\mathrm{it}} & =\text { Corporate risk) } \\
\text { LEVERAGE }_{\mathrm{it}} & =\text { Leverage } \\
\text { SALESGR }_{\mathrm{it}} & =\text { Lales growth } \\
\text { NOL }_{\mathrm{it}} & =\text { Net Operating Loss } \\
\text { INVINT } & =\text { Inventory Intensity }
\end{array}
$$

\section{RESULTS \& DISCUSSION}

Research model proposed in this study were regressed using a common effect model and views 9. Descriptive statistics in table 4.1 shows that CASHETR and RISK in this research tend to be low, while LEVERAGE, SALESGR and INVINT tend to be high. Gender in this research is dominated by men $(83,5 \%)$.

From the table I, it can be concluded that the first hypothesis stated the executive character has a positive effect on tax avoidance is not supported by the data ( $\mathrm{t}$ statistic $4.2017, \alpha 1 \%)$. This study found that the more risk taker an executive, the lower level of the corporate tax avoidance. This results support [5] [6]. This findings may be influenced by their General Provisions and Tax Procedures Law No. 16 of 2009, article 32 paragraph 2 stating that the company leader personally responsible and/or successively for the payment of taxes owed [33]. This rule is binding on all parties who have real authority in determining policy in the company. This provision also applied to the commissioner and the controlling shareholder. Although executive's character at the companies are basically a risk taker, with these law, perhaps in the case of tax avoidance, they tend to be more cautious. The results of descriptive statistics also show that the executives at the

\begin{tabular}{|c|c|c|c|}
\hline \multicolumn{4}{|c|}{$\begin{aligned} \text { Cashetr }= & 0.2909-0.2053 \text { Risk }+0.0497 \text { Gender }-0.0396 \text { Invint }-0.5127 \\
& \text { Leverage }+0.031 \mathrm{Nol}-0.129 \text { Salesgr }\end{aligned}$} \\
\hline Variables & Coefficient & t-Statistik & Probability \\
\hline Risk & -0.2054 & -4.2017 & $0.0001^{* 8 *}$ \\
\hline Gender & 0.0497 & 3.0845 & $0.0025^{* 8 *}$ \\
\hline Invint & -0.0396 & -0.9618 & 0.3381 \\
\hline Lev & -0.5127 & -9.6895 & $0.0000^{* 8 *}$ \\
\hline Nol & 0.0312 & 2.0526 & $0.0423^{* *}$ \\
\hline Salesgr & -0.1294 & -5.1734 & $0.0000^{* 8 *}$ \\
\hline \multicolumn{4}{|c|}{ Adj R-squared $\quad: 0.6003$, Prob(F-statistic) $: 0.0000$} \\
\hline
\end{tabular}
samples classified as risk averse.

TABLE I. DESCRIPTIVE STATISTICS

\begin{tabular}{|l|c|c|c|c|c|c|c|}
\hline & CASHETR & LEVERAGE & SALESGR & INVINT & NOL & RISK & GENDER \\
\hline Mean & 0.248016 & 0.106339 & 0.163008 & 0.247961 & 0.259843 & 0.034134 & 0.834646 \\
\hline Median & 0.256000 & 0.052000 & 0.126000 & 0.211000 & 0.000000 & 0.047000 & 1.000000 \\
\hline Maximum & 0.507000 & 0.741000 & 1.485000 & 0.717000 & 1.000000 & 0.829000 & 1.000000 \\
\hline Minimum & -0.200000 & 0.015000 & -0.399000 & 0.026000 & 0.000000 & -0.384000 & 0.000000 \\
\hline Std. Dev. & 0.101078 & 0.127127 & 0.246771 & 0.144644 & 0.440285 & 0.121003 & 0.372971 \\
\hline Skewness & -1.330742 & 2.593829 & 2.754700 & 1.400937 & 1.095239 & 1.248217 & -1.801592 \\
\hline Kurtosis & 7.291192 & 10.94980 & 15.33214 & 4.333479 & 2.199549 & 18.13524 & 4.245732 \\
\hline Observations & 127 & 127 & 127 & 127 & 127 & 127 & 127 \\
\hline
\end{tabular}

Source: data processed

Hypothesis testing results are presented in the Table 4.2 below.

TABLE II. OUTPUT

2 Source: data processed

Gender in this study proved has a positive influence on tax avoidance. Largely executives in this study were male (83, $5 \%$ ). In this study concluded that male executives more willing to take risks in terms of tax avoidance compared with women executives. Thus it can be concluded that the hypothesis 2 is supported by the data.

\section{CONCLUSION AND SUGGESTION}

This study examined the influence of executive and gender on tax avoidance. The results showed that the executive character negatively affect tax avoidance. While male executives in this study proved to be more courageous in taking tax avoidance risk, when compared with women executives.

This study has a number of limitations. The company's risk as a proxy of executive character in this study only measured by the effective cash tax rate, the next research is expected to use leverage as a proxy. This study made no distinction in leaders of the company, whether as CEO or CFO and investigate its effect on tax avoidance, further research may detail individual effect to the tax avoidance. This study only used manufacturing company in the sample, further research can expand this research by using a sample from diverse industries. Further research can also investigates which is more aggressive in tax avoidance, executive in family and nonfamily firm. This research didn't used match samples for 
gender, future study may used match sample for male and female executive, for better consistency.

\section{REFERENCES}

[1] Surbakti, Theresa Adelina Victoria. (2012). Pengaruh Karakteristik Perusahaan dan Reformasi Perpajakan Terhadap Penghindaran Pajak di perusahaan Manufaktur yang Terdaftar di Bursa Efek Indonesia Tahun 2008-2010. Skripsi. Jurusan Akuntansi Fakultas Ekonomi Universitas Indonesia.

[2] Desai, M and D. Dharmapala. (2008). Corporate Tax Avoidance and Firm value. The Review of Economics and Statistics.

[3] Dyreng, D. Scott, Michelle Hanlon, Edward L. Maydew. (2010). The Effects of Ecexutives on Corporate Tax Avoidance. The Accounting Review. Vol.85. No. 4. 1163-1189.

[4] Budiman, Judi dan Setiyono. (2011). Pengaruh Karakter Eksekutif Terhadap Penghindaran Pajak (Tax Avoidance). Prosiding SNA 15 Banjarmasin.

[5] Swingly, Calvin and I Made Sukartha.( 2015). Pengaruh Karakter Eksekutif, Komite Audit, Ukuran Perusahaan, Leverage dan Sales Growth Pada Tax Avoidance. E-Jurnal Akuntansi. Vol 10. No.1

[6] Butje,S., and Tjondro, E. (2015). Pengaruh Karakter Eksekutif dan Koneksi Politik Terhadap Tax Avoidance. Tax \& Accounting Review, 4(2).

[7] Volscho, Thomas W and Nathan J. Kelly. (2012). The rise of the super rich: power resources, taxes, financial market and the dynamics of the top 1 percent, 1949-2008. American Sociological Review. 77 (5): 679699

[8] Harjanegara, L. Y. (2016). Pengaruh Corporate Governance, Karakter Eksekutif dan Karakteristik Perusahaan Terhadap Tax Avoidance Pada Perusahaan Manufaktur yang Terdaftar Di BEI (Doctoral dissertation, Widya Mandala Catholic University Surabaya).

[9] Francis, Bill and Hasan, Iftekhar and Wu, Qiang and Yan, Meng. (2014). Are Female CFOs Less Tax Aggressive? Evidence from Tax Aggressiveness. Journal of American Taxation Association, Fordham University Schools of Business Research Paper No. 2428541. SSRN:http://ssrn.com/abstract=2428541 or http://dx.doi.org/10.2139/ssr n. 2428541

[10] Aryati, Titik. (2012). Analisis Faktor-Faktor yang Mempengaruhi Tingkat Kepatuhan Wajib Pajak Badan. Media Ekonomi dan Manajemen. Vol.25. No.1.

[11] Fitriyani, D., Prasetyo, E., Yustien, R., and Hizazi, A. (2014). Pengaruh Gender, Latar Belakang Pekerjaan, dan Tingkat Pendidikan Terhadap Kepatuhan Wajib Pajak. InFestasi, 10 (2).

[12] McGee, Robert W. and Yoon, Yeomin and Li, Ye. (2015). The Ethics of Tax Avoidance: A Comparative Study of Chinese and U.S. Opinions . Indonesian Journal of International \& Comparative Law 2(1): 161-186. SSRN: http://ssrn.com/abstract $=2555090$

[13] Aronmwan, Edosa Joshua and Imobhio, Ehichioya and Izedonmi, Famous. (2015). Determinants of Personal Income Tax Compliance: Perception of Nigerian Tax Payers. SSRN:http://ssrn.com/abstract=2619855 or http://dx.doi.org/10.2139/ssr n.2619855

[14] Wei, Wei and McGee, Robert W.(2015). Gender and Attitude Toward the Ethics of Tax Avoidance: A Comparison of European and Asian Views. Journal of Accounting, Ethics and Public Policy, Vol. 16, No. 4. Available at SSRN: http://ssrn.com/abstract=2743048
[15] Basri, Y. M. (2015). Pengaruh Gender, Religiusitas dan Sikap Love Of Money Pada Persepsi Etika Penggelapan Pajak Mahasiswa Akuntasi. Jurnal Ilmiah Akuntansi dan Bisnis, 10 (1).

[16] Zirman. (2015). Pengaruh Penegakan Hukum dan Gender Terhadap Penggelapan Pajak Dimediasi Oleh Moral Pajak. Akuntabilitas. Vol. VIII. No. 2, 133-147

[17] Desai, Mihir, and Dhammika Dharmapala. 2009. Corporate Tax Avoidance and Firm Value. The Review of Economics and Statistics. 91(3): 537-546.

[18] Zhou, Wei and Yonghai Wang. (2014). An empirical Study for Corporate Risk Index: CEO Characteristics Affecting Corporate Risk Taking. Journal of Applied Science. 14 (24) 3520-3525

[19] Kahneman, D and A. Tversky (1979). Prospect Theory: An Analysis of Decision Under Risk. Econometrica, 47: 263-292

[20] Chyz. James Anthony. (2010). Personally tax Aggressive and Firm Level tax Avoidance. Dissertation. The University of Arizona

[21] McGee, Robert W. (2006a). A Survey of International Business Academics on the Ethics of Tax Avoidance. Journal of Accounting, Ethics \& Public Policy, 6(3), 301-352. Reprinted at $\mathrm{http}: / /$ ssrn.com/abstract=803964

[22] McGee, Robert W. (2006b). The Ethics of Tax Avoidance: A Survey of Romanian Business Students and Faculty. The ICFAI Journal of Public Finance, 4(2), 38-68 (2006). Reprinted in Robert W. McGee and Galina G. Preobragenskaya, Accounting and Financial System Reform in Eastern Europe and Asia (pp. 299-334). New York: Springer, 2006. Reprinted at http://ssrn.com/abstract=813345.

[23] Barua, A., L. F. Davidson, D. V. Rama, and S. Thiruvadi. (2010). CFO gender and accruals quality. Accounting Horizons 24 (1): 25-39.

[24] Francis et al. 2013), Francis, B., I. Hasan, J. C. Park, and Q. Wu. 2013. Gender differences in financial reporting decision-making: Evidence from accounting conservatism. Contemporary Accounting Research (forthcoming)

[25] Huang, J., and D. J. Kisgen. (2013). Gender and corporate finance: Are male executives overconfident relative to female executives? Journal of Financial Economics. 108 (3): 822839

[26] Atkinson, S. M., S. B. Baird, and M. B. Frye. 2003. Do female mutual fund managers manage differently? Journal of Financial Research 26 (1): $1-18$.

[27] Kumar, A. (2010). Self-selection and the forecasting abilities of female equity analysts. Journal of Accounting Research. 48 (2): 393-435.

[28] McGee, Robert W. (2014). Gender and the Ethics of Tax Avoidance: An $\begin{array}{lllll}\text { Empirical Study } & \text { of } & 82 & \text { Countries. }\end{array}$ SSRN: http://ssrn.com/abstract=2424893

[29] Paligorova, T. (2010). Corporate risk taking and ownership structure Ottawa, Ontario: Bank of Canada.

[30] Gupta, S and K. Newberry. (1997). Determinants of The Variability in Corporate Effective Tax rates: Evidence From Longitudinal Data. Journal of Accounting and Public Policy. 16 (1): 1-34.

[31] Dewi, N. N. K., and Jati, I. K. (2014). Pengaruh Karakter Eksekutif, Karakteristik Perusahaan, Dan Dimensi Tata Kelola Perusahaan Yang Baik Pada Tax Avoidance Di Bursa Efek Indonesia. E-Jurnal Akuntansi, 6 (2), 249-260.

[32] Faccio, M. M.T. Marchica and R. Mura. (2012). CEO gender, Corporate Risk taking and The Efficiency of Capital Allocation. Working paper No. 2021136, Purdue University. West Lafayette, IN.

[33] Undang Undang Ketentuan Umum dan Tata Cara Perpajakan Nomor 16 Tahun 2009 